\title{
Atmospheric constraints on the methane emissions from the East Siberian Shelf
}

\author{
Antoine Berchet ${ }^{1, \text { a }}$, Philippe Bousquet ${ }^{1}$, Isabelle Pison ${ }^{1}$, Robin Locatelli ${ }^{1}$, Frédéric Chevallier ${ }^{1}$, Jean-Daniel Paris ${ }^{1}$, \\ Ed J. Dlugokencky ${ }^{2}$, Tuomas Laurila ${ }^{3}$, Juha Hatakka ${ }^{3}$, Yrjo Viisanen ${ }^{3}$, Doug E. J. Worthy ${ }^{4}$, Euan Nisbet ${ }^{5}$, \\ Rebecca Fisher $^{5}$, James France ${ }^{5}$, David Lowry ${ }^{5}$, Viktor Ivakhov ${ }^{6}$, and Ove Hermansen ${ }^{7}$ \\ ${ }^{1}$ Laboratoire des Sciences du Climat et de l'Environnement, CEA-CNRS-UVSQ, IPSL, Gif-sur-Yvette, France \\ ${ }^{2}$ NOAA Earth System Research Laboratory, Global Monitoring Division, Boulder, Colorado, USA \\ ${ }^{3}$ Climate and Global Change Research, Finnish Meteorological Institute, Helsinki, Finland \\ ${ }^{4}$ Environment Canada, Toronto, Ontario, Canada \\ ${ }^{5}$ Department of Earth Sciences, Royal Holloway, University of London, Egham, UK \\ ${ }^{6}$ Voeikov Main Geophysical Observatory, St Petersburg, Russia \\ ${ }^{7}$ NILU - Norwegian Institute for Air Research, Kjeller, Norway \\ a now at: Laboratory for Air Pollution/Environmental Technology, Swiss Federal Laboratories for Materials Science and \\ Technology, Empa, Dübendorf, Switzerland
}

Correspondence to: Antoine Berchet (antoine.berchet@empa.ch)

Received: 26 August 2015 - Published in Atmos. Chem. Phys. Discuss.: 17 September 2015

Revised: 17 January 2016 - Accepted: 9 March 2016 - Published: 30 March 2016

\begin{abstract}
Subsea permafrost and hydrates in the East Siberian Arctic Shelf (ESAS) constitute a substantial carbon pool, and a potentially large source of methane to the atmosphere. Previous studies based on interpolated oceanographic campaigns estimated atmospheric emissions from this area at $8-17 \mathrm{TgCH}_{4} \mathrm{yr}^{-1}$. Here, we propose insights based on atmospheric observations to evaluate these estimates. The comparison of high-resolution simulations of atmospheric methane mole fractions to continuous methane observations during the whole year 2012 confirms the high variability and heterogeneity of the methane releases from ESAS. A reference scenario with ESAS emissions of $8 \mathrm{TgCH}_{4} \mathrm{yr}^{-1}$, in the lower part of previously estimated emissions, is found to largely overestimate atmospheric observations in winter, likely related to overestimated methane leakage through sea ice. In contrast, in summer, simulations are more consistent with observations. Based on a comprehensive statistical analysis of the observations and of the simulations, annual methane emissions from ESAS are estimated to range from 0.0 to $4.5 \mathrm{TgCH}_{4} \mathrm{yr}^{-1}$. Isotopic observations suggest a biogenic origin (either terrestrial or marine) of the methane in air masses originating from ESAS during late summer 2008 and 2009.
\end{abstract}

\section{Introduction}

Most long-range global climate projections forecast a warming in the Arctic of $2-8{ }^{\circ} \mathrm{C}$ over the next decades (Collins et al., 2013). Warmer Arctic temperatures could induce the thawing of continental and submarine permafrost and the destabilization of marine hydrates, causing massive methane emissions into the atmosphere, and hence, generating positive feedbacks to the regional and global warming. Monitoring methane emissions at high latitudes in the Northern Hemisphere is therefore of critical importance to anticipate and to interpret future climate changes. The various potential sources emitting methane in the Arctic are identified, but no consensus has been reached concerning their magnitudes. The regional methane budget still has significant uncertainties, revealed by the large spread of the emissions given by the different methods used for its assessment. For example, on one side, emissions of methane by the Arctic tundra estimated by flux observations and process-based models (i.e. bottom-up approaches) for the 2000s have been synthesized, respectively, at 20 [11 to 51] $\mathrm{TgCH}_{4} \mathrm{yr}^{-1}$ and 28 [18 to 37$] \mathrm{TgCH}_{4} \mathrm{yr}^{-1}$ (McGuire et al., 2009). On the other side, top-down atmospheric inversions, based on observations of atmospheric methane mixing 
ratio, show a range for total natural Arctic methane emissions north of $60^{\circ} \mathrm{N}$ of 12 to $28 \mathrm{TgCH}_{4} \mathrm{yr}^{-1}$ (Kirschke et al., 2013), i.e. smaller and slightly narrower than the bottom-up range, but still statistically consistent with bottom-up estimates. In addition, anthropogenic emissions are estimated at 9 [7 to 11$] \mathrm{TgCH}_{4} \mathrm{yr}^{-1}$ above $60^{\circ} \mathrm{N}$ by top-down inversions (Kirschke et al., 2013).

Methane emissions from the Arctic Ocean are lower than land emissions, but more uncertain relatively, as synthesized by McGuire et al. (2009), with a range of 1 to $12 \mathrm{TgCH}_{4} \mathrm{yr}^{-1}$. The East Siberian Arctic Shelf (ESAS), which covers $2 \times 10^{6} \mathrm{~km}^{2}$ or $14 \%$ of the Arctic Ocean, constitutes a large pool of carbon for potential Arctic methane emissions as a large part of Arctic marine permafrost (up to $40 \%$; Ruppel, 2015) is located in this region after the flooding of Siberian tundra during the Holocene transgression (7-15 kyr ago). During thawing, microbial activity can produce a significant amount of methane but the fraction of it reaching the atmosphere remains largely disputed. Marine hydrates are a large pool of subsea methane, with very uncertain global emissions (2-9 $\mathrm{TgCH}_{4} \mathrm{yr}^{-1}$; Kirschke et al., 2013). Based on oceanographic measurements performed over almost a decade, Shakhova et al. (2010) suggested that ESAS emits $8 \mathrm{TgCH}_{4} \mathrm{yr}^{-1}$ into the Arctic atmosphere, which is two-thirds of the $1-12 \mathrm{TgCH}_{4} \mathrm{yr}^{-1}$ range by McGuire et al. (2009). Shakhova et al. (2014) revised the ESAS emissions upwards to $17 \mathrm{TgCH}_{4} \mathrm{yr}^{-1}$, accounting for methane emissions above several oceanic hot spots due to bubbling in the water column and methane degassing to the atmosphere during storms. However, due to very high spatial and temporal variability in methane fluxes, estimates of the ESAS emissions are still uncertain (e.g, Shakhova et al., 2015).

Observations of atmospheric methane mole fractions and of methane isotopes in the Arctic can improve our understanding of the ESAS emissions (Dlugokencky et al., 2011; Fisher et al., 2011). Arctic regional emissions of methane drive the variability of the atmospheric signal at distant locations through transport and mixing. This makes it possible to inversely constrain emissions with atmospheric observations and simulations of transport and mixing. North of $55^{\circ} \mathrm{N}, 22$ atmospheric stations measure methane mole fractions, among which 12 sites provide continuous observations and 3 sites sample the isotopic composition of air on a weekly basis or during intensive campaigns. Although sparse, these stations are well illuminated by ocean and land methane emissions because of the fast horizontal transport of air masses around the North Pole (e.g. Bousquet et al., 2011, and in the Supplement).

In this paper, atmospheric methane observations and highresolution simulations of atmospheric transport in the Arctic are combined to evaluate the potential of an $8 \mathrm{TgCH}_{4} \mathrm{yr}^{-1}$ source from ESAS and to propose atmospheric insights on the magnitude of the ESAS methane emissions. In Sect. 2, the observations and the setup of the transport model are described as well as the statistical analysis used to com- pare simulations to measurements. In Sect. 3.1, simulations from an $8 \mathrm{TgCH}_{4} \mathrm{yr}^{-1}$ reference scenario are compared to observed time series of methane concentrations to assess the likelihood of such a reference scenario. In Sect. 3.2, a comprehensive statistical analysis based on Monte Carlo experiments (described in Sect. 2.4) is carried out to propose a range of ESAS emission magnitudes compatible with circumpolar atmospheric observations. In Sect. 3.3, Arctic isotopic methane measurements are analysed to confirm the geophysical origin of the ESAS methane emissions.

\section{Materials and methods}

\subsection{Observation sites}

This study is based on the statistical analysis of 1 year of synoptic atmospheric signal (days to weeks) reaching atmospheric observation sites. Therefore, continuous observations are needed as weekly or biweekly sampling does not allow us to capture synoptic changes. As the focus here is on emissions from ESAS, continuous observations which are sensitive to these emissions are needed. The year 2012 was chosen as the year with the largest number of available observations at the time the paper was written. The double constraint of data availability and of data sensitivity to the ESAS emissions leaves 4 relevant sites for our analysis (see detailed characteristics in Table 1), out of the 12 observation sites carrying out continuous measurements of atmospheric methane mole fractions around the Arctic Ocean in 2012: one nearby site, Tiksi (TIK), and three remote sites but regularly illuminated by the ESAS emissions, Alert, Barrow, Zeppelin (ALT, BRW, ZEP). In addition to these four sites, we selected one background site, Pallas (PAL), poorly influenced by the ESAS emissions (see Fig. 1) to evaluate the ability of the model to represent Arctic atmospheric methane. The remaining sites are either barely influenced by ESAS (e.g. the Ivittuut site in Greenland, Bonne et al., 2014; or Canadian sites from Environment Canada, Worthy et al., 2003), or local and regional influences are dominant (e.g. fossil fuel and wetland emissions in the Siberian lowlands for observation sites of the JR-STATION network; Sasakawa et al., 2010). TIK is located closest to the shores of the Laptev Sea, a few tens of kilometres only away from the emitting region proposed by Shakhova et al. $(2010,2014)$. BRW and ALT are located at the northern edge of North America, in north Alaska and north Canada, respectively, about 2000$2500 \mathrm{~km}$ away from ESAS but still influenced by this region (see typical footprints in Figs. S2 and S3 in the Supplement). ZEP observatory is operated on a summit of Svalbard island, about $2400 \mathrm{~km}$ away from ESAS (see Fig. S5), but also illuminated by it. When these three remote sites are illuminated by the ESAS emissions, methane-enriched air masses are transported to them directly across the Arctic Ocean in 2-3 days. Therefore, usually no major continental emission 
areas lie along the air mass paths from ESAS to BRW, ZEP or ALT stations. PAL, in northern Scandinavia, is taken as a distant site, with a dominant influence from Europe (see Fig. S4) and very limited influence of Laptev Sea emissions (typical contributions $<2 \mathrm{ppb}$; maximum $20 \mathrm{ppb}$ in a few plumes; Fig. 1). Here, PAL is used for evaluating the capacity of our setup of the Eulerian mesoscale nonhydrostatic chemistry transport model CHIMERE (see Sect. 2.2) to reproduce the methane mole fraction variability at high latitudes and at synoptic scales in a basic scenario (see Sect. 2.3).

The methane mole fractions at the observation sites are analysed with instruments maintained by Environment Canada (EC; ALT), NOAA/Earth System Research Laboratory (NOAA/ESRL; BRW), the Norwegian Institute for Air Research (NILU; ZEP), and the Finnish Meteorological Institute (FMI; PAL and TIK). They are calibrated with standards traceable to the WMO X2004 $\mathrm{CH}_{4}$ mole fraction scale (Dlugokencky et al., 2005). The combined standard uncertainty on individual measurement remains below the $\pm 3.7 \mathrm{ppb}$ requested by the World Meteorological Organization (WMO/GAW, 2009).

The continuous observations are hereafter compared to simulated mixing ratios. Atmospheric transport models have a known bias at nighttime when the vertical mixing close to the surface is very small (e.g. Berchet et al., 2013). This bias deteriorates the model performance in reproducing the influence of local and regional sources to the observation sites during the night. To minimize this documented issue, only afternoon averages of observed mole fractions are compared to simulated equivalents in our analysis.

For enhancing atmospheric insights on the ESAS emissions, especially about the underlying physical processes causing emissions, we also analyse isotope measurements from ZEP with clear identified origin from East Siberia (Fisher et al., 2011). Isotopes measurements of $\delta^{13} \mathrm{C}_{\mathrm{CH}_{4}}$ at ZEP are carried out by the Royal Holloway University of London (RHUL). Five-litre Tedlar bags are collected and analysed with modified gas chromatography isotope ratio mass spectrometry (GC-IRMS) at RHUL (Fisher et al., 2011). Methane emissions from the Arctic Ocean are expected to dominantly come from microbial activity in the ESAS seabed and thawing carbon-rich permafrost as suggested by Shakhova et al. (2010), and less from hydrate methane destabilization. Isotopic compositions measured at ZEP during September 2008 and September-October 2009 are compared to CHIMERE simulations in Sect. 3.3 for assessing methane emission processes in ESAS.

\subsection{Polar CHIMERE transport model}

Atmospheric transport is simulated with the Eulerian mesoscale nonhydrostatic chemistry transport model CHIMERE (Vautard et al., 2001; Menut et al., 2013) over a limited-area domain. The model is constrained by meteorological fields interpolated at a spatial resolution of

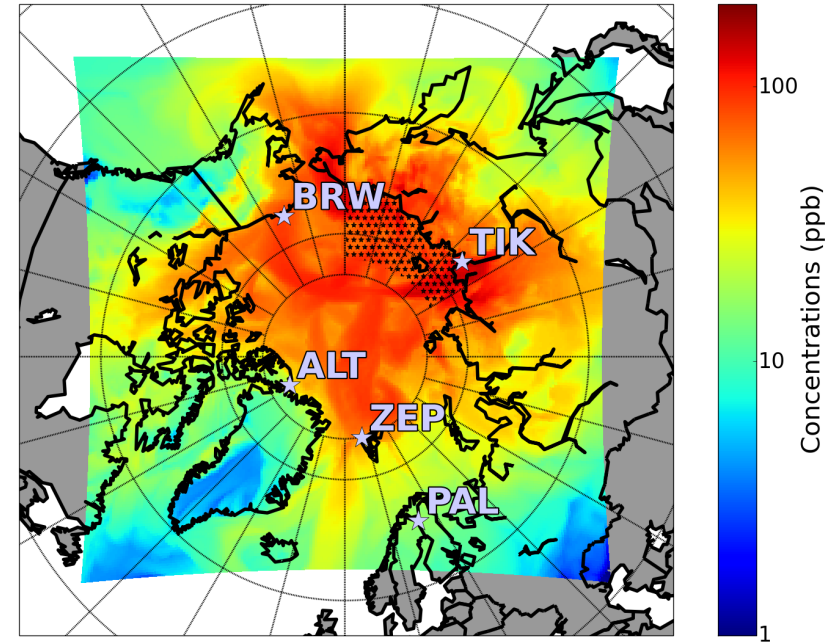

Figure 1. Map of the domain of CHIMERE simulations (see Sect. 2.2) with the area of the ESAS emission (black stars; see Sect. 2.3) and the stations used in the analysis. Shaded colours show the maximum over the whole year 2012 of near-surface simulated influence (in ppb) of the ESAS methane emissions after transport.

$0.5^{\circ} \times 0.5^{\circ}$ every $3 \mathrm{~h}$ from reanalyses of the European Centre for Medium-Range Weather Forecasts (ECMWF, ERAINTERIM; Uppala et al., 2005). The original model has been modified to simulate atmospheric transport over polar regions with a regular kilometric resolution of $35 \times 35 \mathrm{~km}^{2}$ covering all latitudes from $50^{\circ} \mathrm{N}$ up to the North Pole (as illustrated by Fig. 1). Such a kilometric resolution avoids the numerical issues in grid cells becoming very small close to the pole, as is the case for longitude-latitude regular grids. The transport simulations represent the troposphere in the region from the surface to $300 \mathrm{hPa}(\sim 9000 \mathrm{~m})$ with geometrically spaced vertical layers of $10 \mathrm{~m}$ close to the surface and $300 \mathrm{~m}$ in the upper troposphere.

Methane has a lifetime of $8-9$ years regarding oxidation by the $\mathrm{OH}$ radicals (e.g. Voulgarakis et al., 2013). As the focus is put here on synoptic variations within days or weeks of atmospheric methane mole fractions at the surface, methane chemistry is not accounted for in our setup of the model.

\subsection{Transport inputs and emission scenarios}

The regional transport model CHIMERE requires boundary conditions to its limited-area domain: (i) surface emissions within the domain and (ii) lateral and top 3-D concentration fields accounting for transport and emissions outside the domain to force its open sides (lateral and top sides). Lateral boundary 3-D fields of mole fractions are interpolated from global analyses obtained by assimilating surface mole fraction measurements in the global circulation model LMDz (Locatelli et al., 2015). The 3-hourly global analyses at $3.75^{\circ} \times 1.875^{\circ}$ of resolution are interpolated at the lateral and top sides of CHIMERE domain for the required dates. 


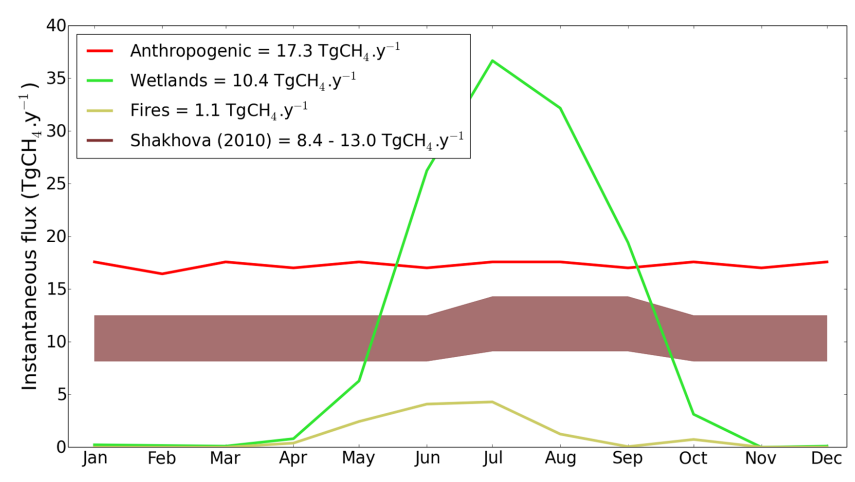

Figure 2. Seasonal cycle of prior emissions as used in the model CHIMERE.

Surface emissions for the CHIMERE domain are deduced from state-of-the-art models and inventories: (1) EDGAR v4.2 FT2010 inventory for anthropogenic emissions (http:// edgar.jrc.ec.europa.eu), (2) LPJ model for wetland emissions (Spahni et al., 2011), (3) GFED v3 model at a daily scale for fire emissions (Giglio et al., 2009; van der Werf et al., 2010), and (4) emissions from ESAS (see below and hatched area in Fig. 1). The EDGAR inventory uses up-to-date economic activity maps by sector, convolved with emission factors estimated in laboratories or with statistical studies (Olivier et al., 2005). LPJ model includes a dynamical simulation of inundated wetland areas (Stocker et al., 2014), dynamic nitrogen cycle (Stocker et al., 2013), and dynamic evolution of peatlands (Spahni et al., 2013; Stocker et al., 2014). The model uses CRU TS 3.21 input data (temperature, precipitation rate, cloud cover, wet days), observed atmospheric $\mathrm{CO}_{2}$, and prescribed nitrogen deposition (Lamarque et al., 2011) for each year for the simulation of dynamic forest and peatland vegetation growth. The GFED v3 database is built from the $500 \mathrm{~m}$ collection 5.1 MODIS DB burned-area mapping algorithm (Giglio et al., 2009). Methane emissions at monthly and daily scales are deduced from the burnt areas using CarnegieAmes-Stanford approach (CASA model; Potter et al., 1993) and emission factors (van der Werf et al., 2010).

EDGAR v4.2 FT2010 reports emissions for the year 2010, and not 2012. Anthropogenic emissions are reported on an annual basis in this inventory and have been found to only change slightly for the Arctic in the fast track recent release for 2012 (http://edgar.jrc.ec.europa.eu/). Moreover, as we analyse synoptic signals here, our results are not very sensitive to small annual changes. We thus directly transpose 2010 anthropogenic emissions to the year 2012. GFED v3 database and LPJ model also do not provide emission fluxes for years later than 2010. We thus take a climatology of biomass burning and wetland emissions computed over the years 2000-2010 to represent fire and wetland emissions in 2012. In the absence of the actual year, this is a conservative approach in order to represent all potential emitting areas for these two sources.
The first three types of emissions are projected from their original grids of $0.1^{\circ} \times 0.1^{\circ}(\mathrm{EDGAR})$ and $0.5^{\circ} \times 0.5^{\circ}(\mathrm{LPJ}$, GFED) to CHIMERE grid. The ESAS emissions are directly built on CHIMERE grid from Shakhova et al. (2010) as they provide a detailed description of the emission areas and emission strengths per period (winter and summer). As it is suggested in Shakhova et al. (2010), hot spots are separated from background emissions and summer fluxes (mid-June to midSeptember) from winter fluxes (the rest of the year). We prescribe uniform and constant emissions by emission type (hot spots and background) and period (summer and winter). Doing so, we underestimate the variability of methane emissions from ESAS, which likely vary on shorter timescales, especially in winter in relation with sea ice breaks and ice displacements after periods of accumulation under the ice. This means that simulated mole fractions are less contrasted with smaller peaks and higher background values than with a more realistic (but unknown) flux map. We scale the ESAS emissions, so that annual emissions are $8 \mathrm{TgCH}_{4} \mathrm{yr}^{-1}$, in the lower range of the previous estimates.

Figure 2 presents the seasonal cycle of prior emissions used as CHIMERE inputs. Anthropogenic emissions are constant over the year, the small variations on the monthly emissions simply coming from the different numbers of days in each month. Wetland and fire emissions have a smooth cycle with high emissions in summer and almost no emissions in winter. Considering the magnitudes of each type of emission, the ESAS emissions are expected to be noticeable in the atmospheric signals, especially in winter.

The four types of emissions are run as separate passive tracers in polar CHIMERE for 2012, which allows the analysis of the contribution of each source separately at observation sites. The combination of the contributions from the four types of emissions and from the transported lateral boundary mole fractions provides the modelled methane mole fractions including the ESAS contribution. The emission scenario not including ESAS emissions is hereafter referred to as the basic scenario; the scenario with ESAS emissions is called the reference scenario. The basic and reference scenarios are compared to observed time series in Sect. 3.1.

\subsection{Statistical assessment of the ESAS emissions}

The magnitude of the ESAS emissions can be derived by adding scaled ESAS emissions to the basic scenario (see Sect. 2.3), so that simulated time series best fit with observed time series (see Eq. (1) below for agreement score definition). However, the emission databases used in the transport model, as well as the lateral boundary conditions and the transport representation itself, suffer from uncertainties. A tolerance interval for magnitude of the ESAS emissions as seen by atmospheric sites is computed through Monte Carlo experiments to account for these uncertainties.

The Monte Carlo ensemble (20000 samples hereafter) is generated by randomly scaling the anthropogenic emissions, 


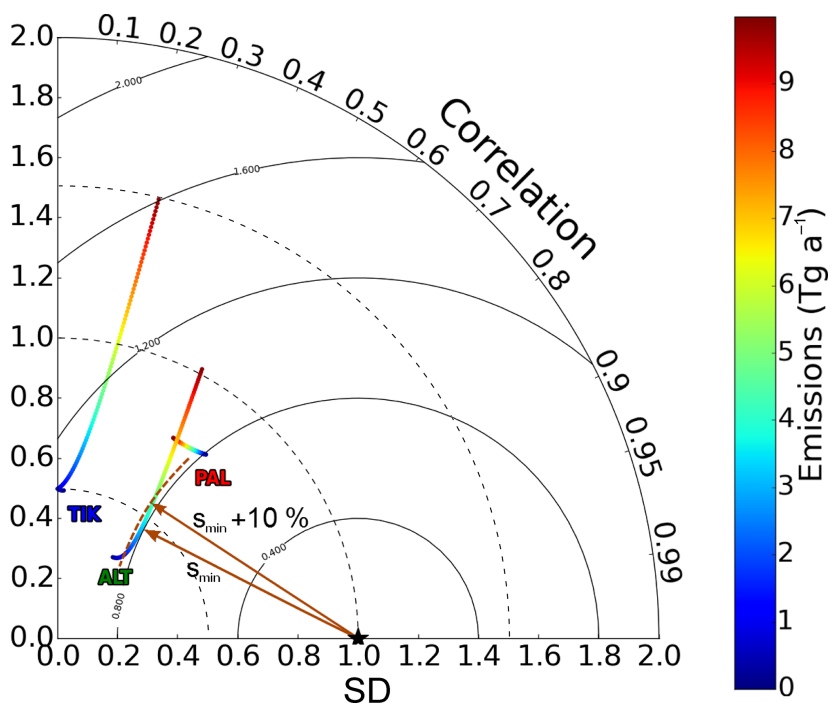

Figure 3. Taylor diagram representation of the statistical analysis of the ESAS emissions (see Sect. 2.4). For each observation site, ESAS emission scenarios from 0 to $10 \mathrm{TgCH}_{4} \mathrm{yr}^{-1}$ are located on the Taylor diagram, depending on the compatibility (correlation and standard deviation) between observations and simulations, thus generating a compatibility trajectory. The Taylor plot is based on a polar projection with the standard deviation as the radius and the correlation coefficient as the polar angle. Point colours depict the ESAS emission magnitude for each scenarios. To compare the different sites, each trajectory has been normalized by the site standard deviation.

the wetland emissions, and the lateral boundary conditions, for each month of the year. The distributions used for these perturbations are Gaussian distributions of, respectively, 50, 75 , and $50 \%$ of errors. In addition to the emission scaling, we also add a random Gaussian noise on the simulated mixing ratios of $60 \mathrm{ppb}$ of standard deviation. This noise on the simulations is expected to represent the errors on the transport and from the imperfect distribution of the emissions. The scaling factors applied on emissions and the random noise in the Monte Carlo sampling have been chosen in the upper range of known uncertainties in the used data sets (e.g. Kirschke et al. (2013) for emissions and Patra et al. (2011) for transport), so that the final uncertainties on the ESAS emissions are not underestimated.

For each Monte Carlo sample $i$ (i.e. a specific perturbed set of anthropogenic emissions, wetlands, and lateral boundary conditions, with added transport noise), model-observations agreement scores $S$ are computed for ESAS emissions from 0 to $20 \mathrm{TgCH}_{4} \mathrm{yr}^{-1}$; other emission rates (wetlands and anthropogenic) are not changed. In Fig. 3, only the range from 0 to $10 \mathrm{TgCH}_{4} \mathrm{yr}^{-1}$ for ESAS emissions is illustrated. The model-observations agreement score $S$ is the sum of the local scores $s$ at ALT, TIK, ZEP, and PAL (BRW is not used in the computation of the score $S$ as no observations are available between June and December 2012). Local scores $s$ are defined by the centred root mean square distance (i.e. the distance to the reference observation point in a Taylor diagram; Taylor, 2001):

$s^{2}=1+\left(\frac{\sigma_{\mathrm{s}}}{\sigma_{\mathrm{o}}}\right)-2 \frac{\sigma_{\mathrm{s}}}{\sigma_{\mathrm{o}}} r$,

where $\sigma_{\mathrm{s}}$ and $\sigma_{\mathrm{o}}$ are the simulated and observed standard deviation and $r$ the correlation coefficient between the observations and the simulations at the selected site.

With this definition of the scores, varying the ESAS emissions results in trajectories in the Taylor diagram, as illustrated in Fig. 3. For all samples $i$ of the Monte Carlo ensemble, we define a minimum agreement score $S_{\min }$, which corresponds to the points of the emission trajectories closest to the reference point (perfect correlation and no bias; black star in Fig. 3). Tolerance intervals $\mathrm{TI}_{i}$ for the ESAS emissions are deduced for all samples of the Monte Carlo ensemble, so that all ESAS emissions with associated scores within $\left[S_{\min }, S_{\min }+10 \%\right]$ are considered compatible with the atmospheric signal. These tolerance intervals are computed for every month of the year 2012. In the end, for each month of the year 2012, we compute aggregated tolerance intervals for the ESAS methane emissions such that $95 \%$ (equivalent to $2 \sigma$ interval for Gaussian distributions) of the Monte Carlo ensemble is within the interval.

This statistical analysis is not performed on the whole available data set, but on afternoon averaged mixing ratios. This processing protocol is widely used in atmospheric quantitative studies and reduces the impact of local emissions notwell mixed in the mesoscale transport model (see Sect. 2.1).

\section{Results}

In the following, simulated mole fractions for the four source contributions described above are compared with methane continuous observations. Then, the Monte Carlo statistical analysis is applied to estimate the methane emissions from ESAS which best fit the atmospheric methane observations. Finally, isotopic remote observations are used to confirm the origin of the ESAS methane emissions.

\subsection{Model-observation comparisons at four Arctic sites}

At PAL, BRW, ZEP, and ALT, as shown in Fig. 4, the continuous methane observations exhibit similar seasonal variations with a minimum during summer (June-July) and a maximum during winter (December-January). At PAL, ZEP, and less evidently at ALT, the synoptic variations appear larger in winter than in summer. At TIK, the seasonal maximum is observed in August, associated with large synoptic variations and a less pronounced seasonal cycle, suggesting an influence of local to regional emissions during summer months.

At PAL, a site scarcely influenced by the ESAS emissions, most of the atmospheric signal is explained by the lateral 


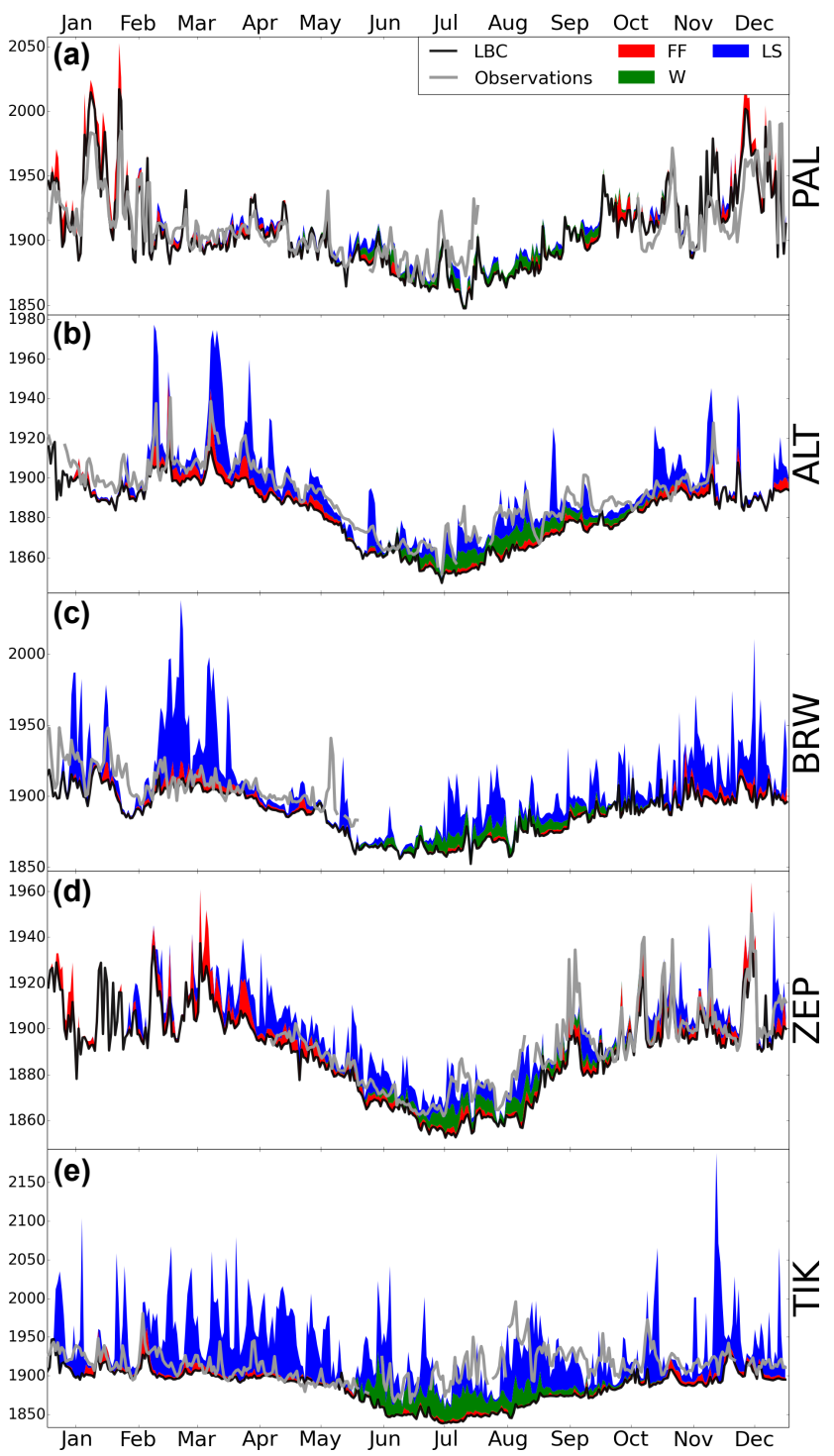

Figure 4. Time series of observed and simulated methane mole fractions at five Arctic sites in 2012. The filled-in areas depict the daily afternoon contributions from wetlands (W, green), fossil fuels and other anthropogenic emissions (FF, red) and from ESAS (LS, blue; $8 \mathrm{TgCH}_{4} \mathrm{yr}^{-1}$ scenario; Sect. 2.3). The LBC line (black) represents the contribution of the lateral boundary conditions transported into the domain. Grey lines are observations (daily averages of continuous measurements). Fire emissions are not represented in this figure due to very low influence on the studied sites.

boundary conditions (i.e. by air masses coming from outside the CHIMERE domain), especially the large synoptic variations during winter months. Polar CHIMERE computed with the basic emission scenario demonstrates a very good skill in winter in representing the atmospheric methane mole fraction variability at high-latitude sites; the performance is slightly less good in summer. As shown in Fig. 4a, the variability of the daily averages' observed methane mole frac- tions is indeed well captured by CHIMERE (annual temporal correlation of $r=0.87$, winter $r=0.89$, summer $r=0.63$; Table 1). Discrepancies between the observed signal and the simulated one at other sites can then be reasonably interpreted in terms of misspecified regional emissions.

At ZEP, ALT, and BRW (Fig 4b, c, and d), three sites remote from ESAS but influenced by long-range transport from ESAS across the Arctic Ocean (see Figs. S2 and S3), nonsummer mole fractions (i.e. all the year but June-September) are well reproduced by the basic scenario $(r=0.87, r=0.79$ and $r=0.76$, respectively). In the reference scenario (see Sect. 2.3), the contribution of ESAS is much too large at ALT, ZEP, and BRW for nonsummer months as shown by the large blue spikes of Fig. 4 between January and April (ALT, BRW), between March and June (ZEP), and between October to December (ALT only, no data available for BRW during summer 2012). Moreover, as discussed in Sect. 2.3, the actual time distribution of the ESAS emissions is not represented. A realistic time distribution would have led to enhanced simulated spikes, reinforcing the inconsistency of winter ESAS fluxes.

In summer, at ALT and ZEP, the fit of the reference scenario to the observations is less favourable than in winter ( $r=0.56$, respectively $r=0.70$ in summer against $r=0.79$, respectively $r=0.87$ in winter for ALT and ZEP). Adding ESAS emissions may fill in some gaps in July-August, less in June and September, though some spikes at ALT are too high and phases are not always in agreement with observations. Some summer peaks from ESAS are very well reproduced by the model (Fig. 4) at ALT and ZEP in July and August. This would suggest that sudden bursts of methane may be released in short periods (typically days) during July and August, with instantaneous rates corresponding to $8 \mathrm{TgCH}_{4} \mathrm{yr}^{-1}$, but a sustained source from ESAS is inconsistent with the observation-simulation comparison.

Getting closer to ESAS, TIK methane observations compared to simulations confirm that the simulated contribution of ESAS emissions from January to April and from October to December is overestimated (Fig. 4e). Indeed, the baseline of observations is well reproduced by the basic scenario, despite some unexplained spikes in winter (Fig. 4e), which slightly decorrelate the fit of the basic scenario to observations $(r=0.56$ in winter; Table 1$)$. These spikes can be attributed either to small and short-term releases of methane from ESAS or to other emissions not properly represented or transported to TIK. In June, the contribution from ESAS is still too large compared to observations. However, from July to September, the observed mole fractions are higher and more variable than the basic scenario. Additionally, from July to September, the simulations decorrelate from the observations at TIK ( $r=-0.04$ in summer), and the average simulations-observations differences are $-36 \mathrm{ppb}$ at TIK in the basic scenario, while they average at $-1 \mathrm{ppb}$ in the reference scenario with ESAS. The same applies to ZEP, where the bias is reduced from -6 to $0 \mathrm{ppb}$ when adding 
Table 1. Observation site characteristics. The site location is displayed in Fig. 1.

\begin{tabular}{|c|c|c|c|c|c|c|c|}
\hline \multirow[b]{2}{*}{ Station } & \multirow[b]{2}{*}{ ID } & \multicolumn{3}{|c|}{ Location } & \multirow[b]{2}{*}{$\begin{array}{l}\text { Network/institute } \\
\text { (data server) }\end{array}$} & \multirow{2}{*}{\multicolumn{2}{|c|}{$\begin{array}{c}\text { Reference } \\
\text { Correlations } r\end{array}$}} \\
\hline & & $\begin{array}{l}\text { Long } \\
\left({ }^{\circ} \mathrm{E}\right)\end{array}$ & $\begin{array}{l}\text { Lat } \\
\left({ }^{\circ} \mathrm{N}\right)\end{array}$ & $\begin{array}{r}\text { Alt } \\
\text { (m a.s.l.) }\end{array}$ & & & \\
\hline Alert & ALT & -62.5 & 82.5 & 200 & $\mathrm{EC}\left(\mathrm{WDCCGG}^{1}\right)$ & 0.79 & 0.56 \\
\hline Barrow & BRW & -156.6 & 71.3 & 11 & NOAA/ESRL $\left(\right.$ ESRL $\left.^{2}\right)$ & 0.76 & - \\
\hline Tiksi & TIK & 128.9 & 71.6 & 29 & FMI $\left(\mathrm{ESRL}^{3}\right)$ & 0.56 & -0.04 \\
\hline Pallas & PAL & 24.12 & 68.0 & 560 & FMI (WDCGG $\left.{ }^{1}\right)$ & 0.89 & 0.63 \\
\hline Zeppelin & ZEP & 11.9 & 79.9 & 475 & $\begin{array}{l}\text { NILU; (Pedersen et al., 2005) } \\
\text { RHUL; (Fisher et al., 2011) }\end{array}$ & 0.87 & 0.70 \\
\hline
\end{tabular}

${ }^{1}$ World Data Centre for Greenhouse Gases (http://ds.data.jma.go.jp/gmd/wdcgg/). ${ }^{2}$ Dlugokencky et al. $(1995,2014)$

$\mathrm{ftp}: / /$ aftp.cmdl.noaa.gov/data/trace_gases/ch $4 /{ }^{3} \mathrm{ftp} / / / \mathrm{ftp}$. etl.noaa.gov/psd3/arctic/tiksi/greenhouse_gas/ghg_concentration/raw/.

the $8 \mathrm{TgCH}_{4} \mathrm{yr}^{-1}$ scenario from ESAS. This suggest emissions from ESAS that are compatible with the $8 \mathrm{TgCH}_{4} \mathrm{yr}^{-1}$ scenario, or even higher, for these 3 months.

However, as confirmed by the footprint analysis at TIK (Fig. S1), observations from July to September are mostly influenced by regional emissions (closer than $200 \mathrm{~km}$ ), including ESAS. Within this radius of influence, wetland emissions from north Yakutia (mainly along Laptev Sea shores between the Lena and Indigirka rivers) could also significantly contribute to observed methane mole fractions at TIK. If such wetlands are poorly represented in the LPJ model at $0.5^{\circ}$ of resolution (either in magnitude or timing), this could dampen the compatibility of the $8 \mathrm{TgCH}_{4} \mathrm{yr}^{-1}$ scenario with TIK observations for summer months. Nevertheless, methane emissions from surrounding wetlands only have a significant influence on TIK site, and not on remote sites, as their magnitude is low compared to the ESAS emissions. The improved compatibility of the reference scenario with ESAS compared to the basic scenario at ZEP from July to September indicates plausible high summer methane emissions from ESAS.

In summary, the emission scenario from Shakhova et al. (2010) shows a large overestimation of methane mole fractions at Arctic stations during all months, except for JulySeptember. Definite conclusions on the exact magnitude of the ESAS methane releases cannot be obtained from TIK alone, due to the regional influence from natural wetlands being possibly not well accounted for, but also to the simplified spatial and temporal scenario used here for the ESAS emissions. The distant observation sites (ZEP, BRW, and ALT) are more likely to provide integrated information about the methane fluxes from ESAS. These three sites indicate that emissions which lead to an annual rate of $8 \mathrm{TgCH}_{4} \mathrm{yr}^{-1}$ cannot be sustained throughout the year, nor identified in the atmosphere except for the months of July to September. In the following, we estimate the ESAS emissions that are compatible with atmospheric observations using a comprehensive statistical approach (see Sect. 2.4), accounting for the uncertainties of our atmospheric approach.

\subsection{Estimation of methane emissions from ESAS}

As seen in Sect. 3.1, PAL is not affected by any change in the simulated ESAS emissions, resulting in a very short trajectory in Fig. 3. This supports its status of background site regarding ESAS emissions. Thus, the Monte Carlo statistical analysis detailed in Sect. 2.4 is mostly influenced by sites well illuminated by ESAS emissions all over the year: ALT, ZEP, and TIK. BRW is not used as 6 months of data are missing in 2012.

Figure 5 shows the monthly methane emissions deduced from the statistical analysis. Despite the large uncertainties prescribed in the Monte Carlo experiment, the posterior uncertainties on the ESAS emissions are low $\left(1 \sigma<1.5 \mathrm{TgCH}_{4} \mathrm{yr}^{-1}\right)$. The signal emitted by ESAS is not correlated with other signals of atmospheric methane in the Arctic, which makes it easier to analyse from the atmospheric point of view. This corroborates that the chosen observation sites are relevant for constraining the ESAS emissions and are robust regarding errors in the quantification method.

The score analysis points at high methane emissions (up to $1.6 \mathrm{TgCH}_{4}$ in July) in summer from July to September, as suggested by the time series in Fig. 4. Mean summer flux rates are estimated to range from 4 to $11.5 \mathrm{TgCH}_{4} \mathrm{yr}^{-1}$, consistent with Shakhova et al. (2010) estimates from intensive summer campaigns. However, for other time periods, which are less documented by in situ campaigns, low emissions are found to range from 0.3 to $1.9 \mathrm{TgCH}_{4} \mathrm{yr}^{-1}$ on average. This is roughly 4 times lower than previous winter estimates. Overall, on a yearly basis, our statistical analysis suggests methane emissions from ESAS to be $0.0-4.5 \mathrm{TgCH}_{4} \mathrm{yr}^{-1}$, somewhat similar to estimates of methane fluxes from the Arctic Ocean north of Canada as deduced from aircraft measurements (Kort et al., 2012).

The estimate computed here is to be considered as an upper bound for the ESAS emissions for the two following reasons. First, the monthly flat temporal emission profile from ESAS in our emission scenario underestimates the impact of the ESAS region on synoptic methane variations at ob- 


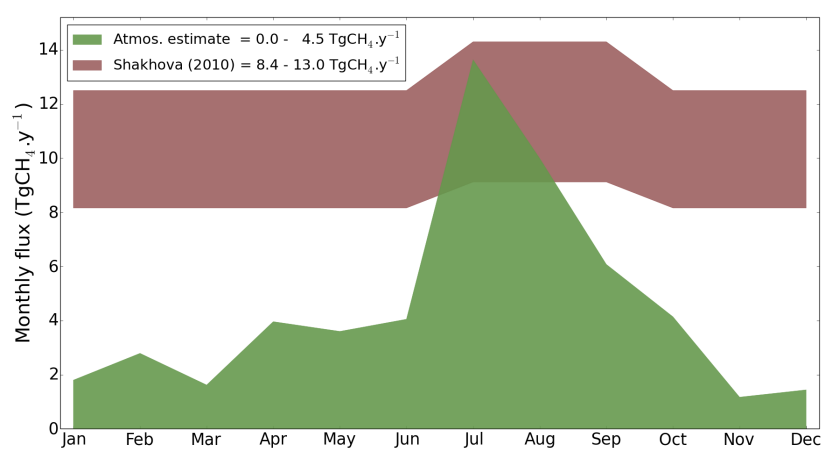

Figure 5. Monthly fluxes in $\mathrm{TgCH}_{4} \mathrm{yr}^{-1}$ as deduced from agreement scores (green; see Sect. 2.4) computed for every month of the year 2012, compared to Shakhova et al. (2010) fluxes (brown).

servation sites. In the real world, concentration peaks due to shorter and more intense methane release from ESAS would be larger, thus reducing further the estimated emissions in order to match atmospheric observations. Second, the local and regional influence of wetland emissions may be systematically underestimated in the global LPJ model at high latitudes (e.g. around TIK station, as suggested by intercomparison of wetland emission models in Siberia; Bohn et al., 2015). We do not fully account for this potential bias in our Monte Carlo analysis as wetland emissions have been rescaled with a centred Gaussian distribution in the Monte Carlo ensemble. Indeed, the most extensive wetland area (a $200-300 \mathrm{~km}$ wide coastal lowland) in the vicinity of TIK is located to the east. Wetland emissions from this area may be either missing or partly displaced in a global model such as LPJ. More work is needed to provide a more realistic regional wetland scenario, but adding such unaccounted for or underestimated wetland emissions would reduce our ESAS emission estimates (in order to match the observed concentration at TIK).

\subsection{Summer isotopic observations in the Arctic}

The isotopic composition in ${ }^{13} \mathrm{C}$ of Arctic air brings insights on the origin of the regional methane sources. Indeed, Arctic surface emissions mixed into the atmosphere own very different isotopic signatures (Fisher et al., 2011; Milkov, 2005): typically of -40 to $-55 \%$ o for gas leaks (thermogenic origin), -52 to $-68 \%$ o for marine hydrates (thermogenic and biogenic origin; range for methane in surface waters), and -60 to $-75 \%$ for wetlands and biological degradation of thawing permafrost (biogenic origin). We use here $\delta^{13} \mathrm{C}$ measured at ZEP in combination with methane concentration measurements in September 2008 (Fisher et al., 2011) and September-October 2009 and compare them to CHIMERE simulations of atmospheric transport for the same period. We assume that the estimation of the ESAS fluxes for late summer 2012 as computed in Sect. 3.2 can be transposed to the periods of isotope measurements in 2008 and 2009. Emis-

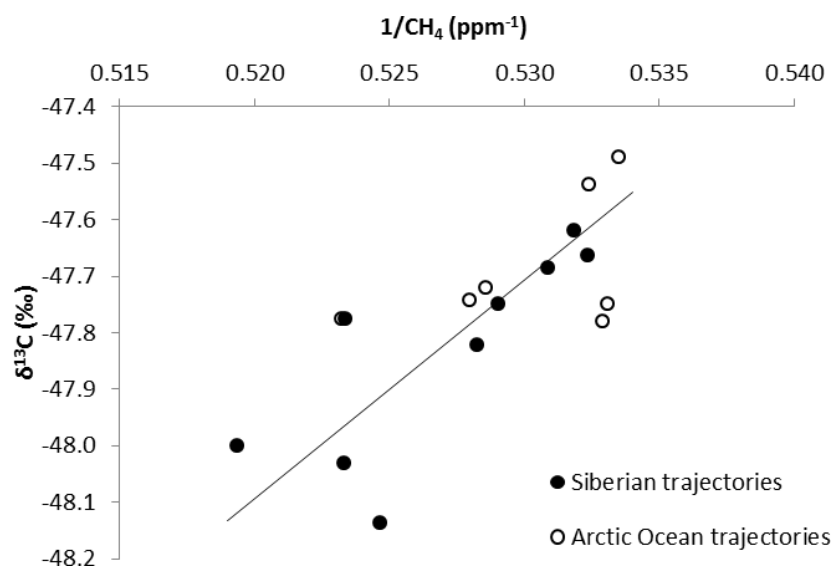

Figure 6. Keeling plot for observations carried out at ZEP observatory in September-October 2009. Only the observations with a dominant origin from ESAS and Siberia or from the Arctic Ocean are kept here. The $y$ axis intercept of the Keeling plot is $-62 \pm 5 \%$.

sions are expected to vary from a year to the other, but this variability is unlikely to impact the qualitative isotopic calculations.

During the observation campaigns, episodes with identified air origin from $\mathrm{Ob}$ River and eastern Siberia exhibited a mean signature of $-65 \pm 3 \%$ in September 2008 (Fisher et al., 2011) and of $-62 \pm 3 \%$ in 2009 (see Fig. 6). These values point toward a dominant biogenic origin of emitted methane. More precisely, in these air masses, the contribution of the different methane sources can be estimated as they are run separately in the CHIMERE model. The ESAS emissions are found to contribute $35-45 \%$ to the observed signals (with ESAS emission strengths of $6 \mathrm{TgCH}_{4} \mathrm{yr}^{-1}$ as computed in Sect. 3.2), continental wetlands contributing to $35-40 \%$ and fossil fuels to $20-25 \%$. Using these relative weights, together with the range of associated isotopic signatures of the sources, it is possible to calculate the integrated isotopic signature of sources at ZEP during the abovementioned episodes. With a scenario of $6 \mathrm{TgCH}_{4} \mathrm{yr}^{-1}$ for ESAS emissions in August-September (as deduced from Sect. 3.2), and depending on the range of the isotopic signature of other sources, it is found that only isotopic signatures in the range of -60 to $-75 \%$ ofor the ESAS source are compatible with the observations. This points at a purely biogenic origin when the sampling was performed. Conversely, if the ESAS emissions were entirely due to degassing of hydrates trapped under the subsea permafrost, the simulated $\delta^{13} \mathrm{C}$ signature at ZEP would be in the range of -52 to $-61 \%$ o thus only marginally compatible with the $\delta^{13} \mathrm{C}$ observations.

Our simple methodology does not allow us to propose a partition of this biogenic contribution between degrading thawing marine permafrost, degassing of marine hydrates, and continental biogenic emissions, which are mostly related to wetlands and freshwaters, but it is possible to eliminate a dominant thermogenic and pyrogenic contribution. To go 
further, a full atmospheric inversion assimilating both ${ }^{13} \mathrm{C}$ and ${ }^{12} \mathrm{C}$ observations in addition to methane concentrations in the transport model would be necessary, which is beyond the scope and objectives of the present paper.

\section{Conclusions}

We suggest some insights on methane emissions from the East Siberian Arctic Shelf using atmospheric methane observations, to complement the intensive in situ oceanographic measurement campaigns carried out mostly in summer in the region. We test the consistency of a methane emission scenario including an $8 \mathrm{TgCH}_{4} \mathrm{yr}^{-1}$ source from ESAS. This scenario is run in a high-resolution model representing Arctic atmospheric transport and confronted to continuous methane concentrations performed at remote and nearby continuous atmospheric stations. The analysis of the modelled and observed time series suggests a large overestimation of the ESAS emissions for all months but summer months, but still a high contribution of the ESAS emissions from July and August, also consistent with isotopic observations. Over 2012, a statistical analysis based on model-observations comparisons is performed to estimate the ESAS emissions and address the uncertainties of our approach. Our method suggests methane emissions from ESAS of $0.0-4.5 \mathrm{TgCH}_{4} \mathrm{yr}^{-1}$. Although significant at the regional scale, especially in summer, these revised emissions are about $2-5$ times smaller than previous estimates from Shakhova et al. (2010) and 6-10 times smaller than the most recent estimates (Shakhova et al., 2014). The time series from the different sites also confirm a very likely heterogeneous temporal variability and spatial distribution, with very short and local methane releases from ESAS. Finally, remote $\delta^{13} \mathrm{C}_{\mathrm{CH}_{4}}$ observations are also used to identify the processes emitting methane in ESAS, pointing at dominant biogenic processes, excluding any thermogenic and pyrogenic processes.

A multi-year analysis with more observation sites and an improved representation of the regional wetland area should be carried out in order to reduce the uncertainties in ESAS emission estimates and to properly identify the sensitivity of the emissions to the ice cover or to other meteorological conditions and the distribution and short-scale variability of the fluxes. The use of another transport model would also be important to address biases in the representation of transport, not addressed by our statistical analysis based on centred perturbations. The development of continuous ${ }^{13} \mathrm{CH}_{4}$ observations at Arctic sites, now possible through laser spectrometry, would provide additional constraints for partitioning emissions between marine hydrates, gas leaks, thawing permafrost, and continental wetlands. Finally, the observatories operated around the Arctic Ocean could also provide more quantitative estimates of Arctic emissions from ESAS using direct and inverse modelling of both methane and ${ }^{13} \mathrm{CH}_{4} \mathrm{ob}-$ servations.

\author{
The Supplement related to this article is available online \\ at doi:10.5194/acp-16-4147-2016-supplement.
}

Acknowledgements. We thank the principal investigator from the observation sites we used for maintaining methane measurements at high latitudes and sharing their data. We are grateful to the anonymous referees for their valuable comments which led to a substantial improvement in the presentation of the paper. We also thank Patrick Crill (Department of Geological Sciences, Stockholm University) for his kind advice and remarks on the manuscript and F. Marabelle (LSCE) and the LSCE IT team for the computer resources. This study was supported by the CEA, ANR-CLIMSLIP project, and iZomet Franco-Swedish project.

Edited by: M. Heimann

\section{References}

Berchet, A., Pison, I., Chevallier, F., Bousquet, P., Conil, S., Geever, M., Laurila, T., Lavrič, J., Lopez, M., Moncrieff, J., Necki, J., Ramonet, M., Schmidt, M., Steinbacher, M., and Tarniewicz, J.: Towards better error statistics for atmospheric inversions of methane surface fluxes, Atmos. Chem. Phys., 13, 7115-7132, doi:10.5194/acp-13-7115-2013, 2013.

Bohn, T. J., Melton, J. R., Ito, A., Kleinen, T., Spahni, R., Stocker, B. D., Zhang, B., Zhu, X., Schroeder, R., Glagolev, M. V., Maksyutov, S., Brovkin, V., Chen, G., Denisov, S. N., Eliseev, A. V., Gallego-Sala, A., McDonald, K. C., Rawlins, M. A., Riley, W. J., Subin, Z. M., Tian, H., Zhuang, Q., and Kaplan, J. O.: WETCHIMP-WSL: intercomparison of wetland methane emissions models over West Siberia, Biogeosciences, 12, 3321-3349, doi:10.5194/bg-12-3321-2015, 2015.

Bonne, J.-L., Masson-Delmotte, V., Cattani, O., Delmotte, M., Risi, C., Sodemann, H., and Steen-Larsen, H. C.: The isotopic composition of water vapour and precipitation in Ivittuut, southern Greenland, Atmos. Chem. Phys., 14, 4419-4439, doi:10.5194/acp-14-4419-2014, 2014.

Bousquet, P., Ringeval, B., Pison, I., Dlugokencky, E. J., Brunke, E.G., Carouge, C., Chevallier, F., Fortems-Cheiney, A., Frankenberg, C., Hauglustaine, D. A., Krummel, P. B., Langenfelds, R. L., Ramonet, M., Schmidt, M., Steele, L. P., Szopa, S., Yver, C., Viovy, N., and Ciais, P.: Source attribution of the changes in atmospheric methane for 2006-2008, Atmos. Chem. Phys., 11, 3689-3700, doi:10.5194/acp-11-3689-2011, 2011.

Collins, M., Knutti, R., Arblaster, J., Dufresne, J., Fichefet, T., Friedlingstein, P., Gao, X., Gutowski, W., Johns, T., Krinner, G., Shongwe, M., Tebaldi, C., Weaver, A., and Wehner, M.: Long-term Climate Change: Projections, Commitments and Irreversibility, in: Climate Change 2013: The Physical Science Basis, Contribution of Working Group I to the Fifth Assessment Report of the Intergovernmental Panel on Climate Change, edited by: Stocker, T., Qin, D., Plattner, G., Tignor, M., Allen, S., Boschung, J., Nauels, A., Xia, Y., Bex, V., and Midgley, P., Cambridge University Press, Cambridge, 2013. 
Dlugokencky, E. J., Steele, L. P., Lang, P. M., and Masarie, K. A.: Atmospheric methane at Mauna Loa and Barrow observatories: Presentation and analysis of in situ measurements, J. Geophys. Res.-Atmos., 100, 23103-23113, doi:10.1029/95JD02460, 1995.

Dlugokencky, E. J., Myers, R. C., Lang, P. M., Masarie, K. A., Crotwell, A. M., Thoning, K. W., Hall, B. D., Elkins, J. W., and Steele, L. P.: Conversion of NOAA atmospheric dry air $\mathrm{CH}_{4}$ mole fractions to a gravimetrically prepared standard scale, J. Geophys. Res., 110, D18306, doi:10.1029/2005JD006035, 2005.

Dlugokencky, E. J., Nisbet, E. G., Fisher, R., and Lowry, D.: Global atmospheric methane: budget, changes and dangers, Philos. T. R. Soc. A, 369, 2058-2072, doi:10.1098/rsta.2010.0341, 2011.

Dlugokencky, E. J., Crotwell, A. M., Lang, P. M., and Masarie, K. A.: Atmospheric methane dry air mole Fractions from quasicontinuous measurements at Barrow, Alaska and Mauna Loa, Hawaii, 1986-2013, ftp://aftp.cmdl.noaa.gov/data/greenhouse_ gases/ch4/in-situ/surface/ (last access: 22 March 2016), 2014.

Fisher, R. E., Sriskantharajah, S., Lowry, D., Lanoisellé, M., Fowler, C. M. R., James, R. H., Hermansen, O., Lund Myhre, C., Stohl, A., Greinert, J., Nisbet-Jones, P. B. R., Mienert, J., and Nisbet, E. G.: Arctic methane sources: Isotopic evidence for atmospheric inputs, Geophys. Res. Lett., 38, L21803, doi:10.1029/2011GL049319, 2011.

Giglio, L., Loboda, T., Roy, D. P., Quayle, B., and Justice, C. O.: An active-fire based burned area mapping algorithm for the MODIS sensor, Remote Sens. Environ., 113, 408-420, doi:10.1016/j.rse.2008.10.006, 2009.

Kirschke, S., Bousquet, P., Ciais, P., Saunois, M., Canadell, J. G., Dlugokencky, E. J., Bergamaschi, P., Bergmann, D., Blake, D. R., Bruhwiler, L., Cameron-Smith, P., Castaldi, S., Chevallier, F., Feng, L., Fraser, A., Heimann, M., Hodson, E. L., Houweling, S., Josse, B., Fraser, P. J., Krummel, P. B., Lamarque, J.-F., Langenfelds, R. L., Le Quéré, C., Naik, V., O’Doherty, S., Palmer, P. I., Pison, I., Plummer, D., Poulter, B., Prinn, R. G., Rigby, M., Ringeval, B., Santini, M., Schmidt, M., Shindell, D. T., Simpson, I. J., Spahni, R., Steele, L. P., Strode, S. A., Sudo, K., Szopa, S., van der Werf, G. R., Voulgarakis, A., van Weele, M., Weiss, R. F., Williams, J. E., and Zeng, G.: Three decades of global methane sources and sinks, Nat. Geosci., 6, 813-823, doi:10.1038/ngeo1955, 2013.

Kort, E. A., Wofsy, S. C., Daube, B. C., Diao, M., Elkins, J. W., Gao, R. S., Hintsa, E. J., Hurst, D. F., Jimenez, R., Moore, F. L., Spackman, J. R., and Zondlo, M. A.: Atmospheric observations of Arctic Ocean methane emissions up to $82^{\circ}$ north, Nat. Geosci., 5, 318-321, doi:10.1038/ngeo1452, 2012.

Lamarque, J.-F., Kyle, G. P., Meinshausen, M., Riahi, K., Smith, S. J., Vuuren, D. P. V., Conley, A. J., and Vitt, F.: Global and regional evolution of short-lived radiatively-active gases and aerosols in the Representative Concentration Pathways, Climatic Change, 109, 191-212, doi:10.1007/s10584-011-0155-0, 2011.

Locatelli, R., Bousquet, P., Hourdin, F., Saunois, M., Cozic, A., Couvreux, F., Grandpeix, J.-Y., Lefebvre, M.-P., Rio, C., Bergamaschi, P., Chambers, S. D., Karstens, U., Kazan, V., van der Laan, S., Meijer, H. A. J., Moncrieff, J., Ramonet, M., Scheeren, H. A., Schlosser, C., Schmidt, M., Vermeulen, A., and Williams, A. G.: Atmospheric transport and chemistry of trace gases in LMDz5B: evaluation and implications for inverse modelling, Geosci. Model Dev., 8, 129-150, doi:10.5194/gmd-8-129-2015, 2015.
McGuire, A. D., Anderson, L. G., Christensen, T. R., Dallimore, S., Guo, L., Hayes, D. J., Heimann, M., Lorenson, T. D., Macdonald, R. W., and Roulet, N.: Sensitivity of the carbon cycle in the Arctic to climate change, Ecol. Monogr., 79, 523-555, doi:10.1890/08-2025.1, 2009.

Menut, L., Bessagnet, B., Khvorostyanov, D., Beekmann, M., Blond, N., Colette, A., Coll, I., Curci, G., Foret, G., Hodzic, A., Mailler, S., Meleux, F., Monge, J.-L., Pison, I., Siour, G., Turquety, S., Valari, M., Vautard, R., and Vivanco, M. G.: CHIMERE 2013: a model for regional atmospheric composition modelling, Geosci. Model Dev., 6, 981-1028, doi:10.5194/gmd6-981-2013, 2013.

Milkov, A. V.: Molecular and stable isotope compositions of natural gas hydrates: A revised global dataset and basic interpretations in the context of geological settings, Org. Geochem., 36, 681-702, doi:10.1016/j.orggeochem.2005.01.010, 2005.

Olivier, J. G. J., Van Aardenne, J. A., Dentener, F. J., Pagliari, V., Ganzeveld, L. N., and Peters, J. A. H. W.: Recent trends in global greenhouse gas emissions:regional trends 1970-2000 and spatial distributionof key sources in 2000, Environm. Sci., 2, 81-99, doi:10.1080/15693430500400345, 2005.

Patra, P. K., Houweling, S., Krol, M., Bousquet, P., Belikov, D., Bergmann, D., Bian, H., Cameron-Smith, P., Chipperfield, M. P., Corbin, K., Fortems-Cheiney, A., Fraser, A., Gloor, E., Hess, P., Ito, A., Kawa, S. R., Law, R. M., Loh, Z., Maksyutov, S., Meng, L., Palmer, P. I., Prinn, R. G., Rigby, M., Saito, R., and Wilson, C.: TransCom model simulations of $\mathrm{CH}_{4}$ and related species: linking transport, surface flux and chemical loss with $\mathrm{CH}_{4}$ variability in the troposphere and lower stratosphere, Atmos. Chem. Phys., 11, 12813-12837, doi:10.5194/acp-11-12813-2011, 2011.

Pedersen, I.-T., Holmén, K., and Hermansen, O.: Atmospheric methane at Zeppelin Station in Ny-Ålesund: Presentation and analysis of in situ measurements, J. Environ. Monitor., 7, 488492, doi:10.1039/B416934D, 2005.

Potter, C. S., Randerson, J. T., Field, C. B., Matson, P. A., Vitousek, P. M., Mooney, H. A., and Klooster, S. A.: Terrestrial ecosystem production: A process model based on global satellite and surface data, Global Biogeochem. Cy., 7, 811-841, doi:10.1029/93GB02725, 1993.

Ruppel, C.: Permafrost-Associated Gas Hydrate: Is It Really Approximately $1 \%$ of the Global System?, J. Chem. Eng. Data, 60, 429-436, doi:10.1021/je500770m, 2015.

Sasakawa, M., Shimoyama, K., Machida, T., Tsuda, N., Suto, H., Arshinov, M., Davydov, D., Fofonov, A., Krasnov, O., Saeki, T., Koyama, Y., and Maksyutov, S.: Continuous measurements of methane from a tower network over Siberia, Tellus B, 62, 403416, doi:10.1111/j.1600-0889.2010.00494.x, 2010.

Shakhova, N., Semiletov, I., Salyuk, A., Yusupov, V., Kosmach, D., and Gustafsson, O.: Extensive Methane Venting to the Atmosphere from Sediments of the East Siberian Arctic Shelf, Science, 327, 1246-1250, doi:10.1126/science.1182221, 2010.

Shakhova, N., Semiletov, I., Leifer, I., Sergienko, V., Salyuk, A., Kosmach, D., Chernykh, D., Stubbs, C., Nicolsky, D., Tumskoy, V., and Gustafsson, R.: Ebullition and storm-induced methane release from the East Siberian Arctic Shelf, Nat. Geosci., 7, 64 70, doi:10.1038/ngeo2007, 2014.

Shakhova, N., Semiletov, I., Sergienko, V., Lobkovsky, L., Yusupov, V., Salyuk, A., Salomatin, A., Chernykh, D., Kosmach, D., Panteleev, G., Nicolsky, D., Samarkin, V., Joye, S., Charkin, A., Du- 
darev, O., Meluzov, A., and Gustafsson, O.: The East Siberian Arctic Shelf: towards further assessment of permafrost-related methane fluxes and role of sea ice, Philos. T. R. Soc. A, 373, 2052, doi:10.1098/rsta.2014.0451, 2015.

Spahni, R., Wania, R., Neef, L., van Weele, M., Pison, I., Bousquet, P., Frankenberg, C., Foster, P. N., Joos, F., Prentice, I. C., and van Velthoven, P.: Constraining global methane emissions and uptake by ecosystems, Biogeosciences, 8, 1643-1665, doi:10.5194/bg8-1643-2011, 2011.

Spahni, R., Joos, F., Stocker, B. D., Steinacher, M., and Yu, Z. C.: Transient simulations of the carbon and nitrogen dynamics in northern peatlands: from the Last Glacial Maximum to the 21st century, Clim. Past, 9, 1287-1308, doi:10.5194/cp-9-1287-2013, 2013.

Stocker, B. D., Roth, R., Joos, F., Spahni, R., Steinacher, M., Zaehle, S., Bouwman, L., Xu-Ri, and Prentice, I. C.: Multiple greenhouse-gas feedbacks from the land biosphere under future climate change scenarios, Nature Climate Change, 3, 666-672, doi:10.1038/nclimate1864, 2013.

Stocker, B. D., Spahni, R., and Joos, F.: DYPTOP: a costefficient TOPMODEL implementation to simulate sub-grid spatio-temporal dynamics of global wetlands and peatlands, Geosci. Model Dev., 7, 3089-3110, doi:10.5194/gmd-7-30892014, 2014.

Taylor, K. E.: Summarizing multiple aspects of model performance in a single diagram, J. Geophys. Res.-Atmos., 106, 7183-7192, doi:10.1029/2000JD900719, 2001.

Uppala, S. M., Kållberg, P. W., Simmons, A. J., Andrae, U., Bechtold, V. D. C., Fiorino, M., Gibson, J. K., Haseler, J., Hernandez, A., Kelly, G. A., Li, X., Onogi, K., Saarinen, S., Sokka, N., Allan, R. P., Andersson, E., Arpe, K., Balmaseda, M. A., Beljaars, A. C. M., Berg, L. V. D., Bidlot, J., Bormann, N., Caires, S., Chevallier, F., Dethof, A., Dragosavac, M., Fisher, M., Fuentes, M., Hagemann, S., Hólm, E., Hoskins, B. J., Isaksen, L., Janssen, P. a. E. M., Jenne, R., Mcnally, A. P., Mahfouf, J.-F., Morcrette, J.-J., Rayner, N. A., Saunders, R. W., Simon, P., Sterl, A., Trenberth, K. E., Untch, A., Vasiljevic, D., Viterbo, P., and Woollen, J.: The ERA-40 re-analysis, Q. J. Roy. Meteor. Soc., 131, 29613012, doi:10.1256/qj.04.176, 2005. van der Werf, G. R., Randerson, J. T., Giglio, L., Collatz, G. J., Mu, M., Kasibhatla, P. S., Morton, D. C., DeFries, R. S., Jin, Y., and van Leeuwen, T. T.: Global fire emissions and the contribution of deforestation, savanna, forest, agricultural, and peat fires (19972009), Atmos. Chem. Phys., 10, 11707-11735, doi:10.5194/acp10-11707-2010, 2010.

Vautard, R., Beekmann, M., Roux, J., and Gombert, D.: Validation of a hybrid forecasting system for the ozone concentrations over the Paris area, Atmos. Environ., 35, 2449-2461, doi:10.1016/S1352-2310(00)00466-0, 2001.

Voulgarakis, A., Naik, V., Lamarque, J.-F., Shindell, D. T., Young, P. J., Prather, M. J., Wild, O., Field, R. D., Bergmann, D., CameronSmith, P., Cionni, I., Collins, W. J., Dalsøren, S. B., Doherty, R. M., Eyring, V., Faluvegi, G., Folberth, G. A., Horowitz, L. W., Josse, B., MacKenzie, I. A., Nagashima, T., Plummer, D. A., Righi, M., Rumbold, S. T., Stevenson, D. S., Strode, S. A., Sudo, K., Szopa, S., and Zeng, G.: Analysis of present day and future $\mathrm{OH}$ and methane lifetime in the ACCMIP simulations, Atmos. Chem. Phys., 13, 2563-2587, doi:10.5194/acp-13-25632013, 2013.

WMO/GAW: Guidelines for the Measurement of Methane and Nitrous Oxide and their Quality Assurance (WMO/TD-No. 1478), Tech. Rep. 185, World Meteorological Organization Global Atmospheric Watch, Geneva, Switzerland, http://www.wmo.int/ pages/prog/arep/gaw/documents/Final_GAW_206_web.pdf (last access: 22 March 2016), 2009.

Worthy, D. E. J., Platt, A., Kessler, R., Ernst, M., and Racki, S.: The Greenhouse Gases Measurement Program, Measurement Procedures and Data Quality, Tech. rep., Meteorological Service of Canada, Canada, 2003. 